was that a satisfactory response to oral and parenteral diuretics occurred after dialysis, as has been reported by Mailloux et al. (1967) after using this technique in intractable chronic congestive heart failure.

So far our experience of peritoneal dialysis for pulmonary oedema after acute myocardial infarction is small, because nearly all patients respond to oral or intravenous diuretics. Nevertheless, since we believe that two of the four patients survived as a result of the procedure, we feel that it should be considered as an emergency measure when this problem is encountered.

We are grateful to Dr. A. E. Pratt, Consultant Radiologist, Kingston General Hospital, for his help in evaluating the chest radiographs.
REFERENCES

Bertrand, E., and Guerin, J. (1961). Médecine Tropicale, 21, 603.

Cairns, K. B., Porter, G. A., Kloster, F. E., Bristow, J. D., and Griswold, H. E. (1968). American Heart fournal, 76, 227.

Chatterjee, K., Harris, A., and Leatham, A. (1969). Lancet, 2, 1061.

MacKenzie, G. J., et al. (1964). Lancet, 2, 825.

McNicol, M. W., et al. (1965). British Medical fournal, 2, 1270.

Mailloux, L. U., et al. (1967). Fournal of the American Medical Association, 199, 873.

Nora, J. J., Trygstad, C. W., Mangos, J. A., 'Sibbons, J. E., and Jegier, W. (1966). Fournal of Pediatrics, 68, 693.

Paulk, E. A., jun., and Hurst, J. W. (1966). American fournal of Cardiology, 17, 695 .

Peel, A. A. F., Semple, T., Wang, I., Lancaster W. M., and Dall, J. L. G. (1962). British Heart fournal, 24, 745.

Rosenbaum, F. F., and Levine, S. A. (1941). Archives of Internal Medicine, $68,913$.

Schneierson, S. J. (1949). American fournal of the Medical Sciences, 218, 76 .

Scott, M. E., Geddes, J. S., Patterson, G. C., Adgey, A. A. J., and Pantridge, J. F. (1967). Lancet, 2, 1382.

Tattersfield, A. E., McNicol, M. W., Shawdon, H., and Rolfe, D. (1969). British Medical fournal, 3, 332.

World Health Organization (1959). World Health Organization. Technical Report Series, No. 168.

\title{
Vancomycin for Staphylococcal Shunt Site Infections in Patients on Regular Haemodialysis
}

\author{
SUSANNAH EYKYN, ${ }^{*}$ M.B. ; IAN PHILLIPS, $\dagger$ M.D., M.R.C.PATH. ; JOHN EVANS, $\ddagger$ M.B.
}

\begin{abstract}
Cummary: Six anuric patients with Scribner shunt site infections were treated by intermittent infusion of vancomycin into the shunt, and a satisfactory clinical response was obtained in five. Serum levels of the antibiotic were estimated frequently. From estimating serum levels and the minimum inhibitory concentrations of vancomycin for a range of hospital staphylococci a dose of 1g. vancomycin every seven days is recommended as a suitable schedule for treating staphylococcal infection in this situation.
\end{abstract}

\section{Introduction}

Vancomycin was first isolated in 1956 from Streptomyces orientalis and shown to be highly active in vitro against Gram-positive organisms. It is bactericidal in concentrations not much greater than those needed to achieve bacteriostasis, natural resistance to the drug is rare, and acquired resistance has not been reported. Vancomycin has, however, been of only limited clinical use, firstly because it must be given by intravenous infusion for systemic effect, secondly because it is ototoxic at excessively high serum levels, and, finally, because there are other non-toxic drugs with equally good bactericidal activity against staphylococci and streptococci.

Great care is needed in the use of vancomycin when renal function is impaired; Dutton and Elmes (1959) found severe loss of auditory acuity in four, possibly five, of nine patients after treatment with vancomycin, all of whom had some degree of renal failure. Geraci et al. (1958) reported perceptive deafness occurring in two patients, one of whom had renal insufficiency, with serum vancomycin levels of $80-100$ $\mu \mathrm{g} . / \mathrm{ml}$. The critical serum level below which eighth nerve toxicity does not occur is not known.

When shunt site infections occur in patients on haemodialysis the organisms isolated are very often staphylococci, either coagulase-positive or coagulase-negative.

\footnotetext{
* Lecturer, Department of Clinical Microbiology.

+ Senior Lecturer, Department of Clinical Microbiology.

$¥$ Senior House Officer, Renal Unit, St. Thomas's Hospital, London S.E.1.
}

Prompt effective treatment is essential to save the shunt and to avoid septicaemia. Ideally the antibiotic selected should be bactericidal, should have good antistaphylococcal activity, and should not be largely removed by haemodialysis, so that it can be given by intermittent infusion into the shunt. In these patients repeated intramuscular injections are best avoided because of the need for heparinization, and oral antibiotics often lead to nausea and vomiting. Vancomycin is particularly suitable for treatment of shunt site infections: it is bactericidal, highly active against staphylococci, is normally almost entirely excreted by the kidney, and is not removed by dialysis (Lindholm and Murray, 1966). . Intermittent administration will therefore produce therapeutic levels in anuric patients which persist for some time.

\section{Patients and Methods}

Sensitivity of Staphylococci to Vancomycin.-Minimum inhibitory concentrations of vancomycin were determined for a range of hospital staphylococci, D.S.T. agar (Oxoid) with an inoculum of $0.02 \mathrm{ml}$. of a broth culture containing about $10^{4}$ organisms per ml. being used. The results were read after 24 hours' incubation. The staphylococci tested included both coagulase-positive and coagulase-negative strains; they were selected to include a range of sensitivities to other antibiotics and many showed multiple resistance.

Patients.-Six patients (four men, two women) aged 19-32 years were treated with vancomycin for shunt site infections. All were having regular haemodialysis for end-stage renal failure and two were anephric. Swabs for bacteriobogical examination were taken from the shunt site of each patient before vancomycin was given and in three cases the minimum inhibitory concentration of vancomycin was determined for the organism isolated. Further cultures were taken from some patients during treatment. The initial dose of vancomycin was $1 \mathrm{~g}$. in four patients and $0.5 \mathrm{~g}$. in two; these doses were repeated when the serum level of the drug fell below a therapeutic level. The antibiotic was given by slow infusion into the venous line during the final 30 to 60 minutes of dialysis. Three of the six patients were also treated with intermittent 
topical fusidic acid (Fucidin) on the shunt site. Treatment with vancomycin was continued for six weeks in four patients and for seven weeks in two.

Method of Assay of Serum Vancomycin.-The serum vancomycin level was measured with an agar diffusion method in a plate 38 by $25 \mathrm{~cm}$., with wells of about $8 \mathrm{~mm}$. diameter cut in the agar. The indicator organism used was Bacillus subtilis A.T.C.C. 6633 and the medium was Difco No. 5 agar. Standards were set up in human serum in doubling dilutions from $100 \mu \mathrm{g}$. to $0.78 \mu \mathrm{g}$. of vancomycin per $\mathrm{ml}$. The assay plates were kept at $4^{\circ} \mathrm{C}$. for two hours to allow prediffusion of the antibiotic, and then incubated overnight at $37^{\circ} \mathrm{C}$. A minimum of two estimations of the vancomycin level was performed on each sample and the mean reading taken.

\section{Results}

Sensitivity of Staphylococci.-The minimum inhibitory concentrations obtained for 62 hospital staphylococci (52 coagulase positive, 10 coagulase negative) are shown in

TABLE I.-Mean Inhibitory Concentrations of Vancomycin for 52 Coagulase-positive and 10 Coagulase-negative Staphylococci

\begin{tabular}{lll|c|c|c|c|c} 
& & \multicolumn{3}{|c}{$\begin{array}{c}\text { Mean Inhibitory Concentration of } \\
\text { Vancomycin }(\mu \mathrm{g} . / \mathrm{ml} .)\end{array}$} \\
\hline $\begin{array}{l}\text { No. of strains positive } \\
\text { No. of strains negative }\end{array}$ & $\ldots$ & $\ldots$ & $\ldots$ & 46 & 5 & 1 & -10 \\
\hline
\end{tabular}

Table I. Of the 52 coagulase-positive staphylococci $51(98 \%)$ were inhibited by $2.5 \mu \mathrm{g}$. or less of vancomycin per ml. and 46 of them by $1.2 \mu \mathrm{g} . / \mathrm{ml}$. The 10 coagulase-negative staphylococci had rather higher minimum inhibitory concentrations, one organism requiring $10 \mu \mathrm{g}$ of vancomycin per $\mathrm{ml}$. for inhibition.

Clinical Response.-Details of vancomycin dosage, length of treatment, bacteriology, and clinical response for each of the six patients treated are shown in Table II. Four of the shunt sites were infected with coagulase-positive staphylococci and one with a coagulase-negative staphylococcus. In spite of repeated attempts to culture an organism in Case 3, nothing was grown, though the shunt site was obviously clinically infected. Vancomycin produced clinical and bacteriological improvement in five of the six shunt site infections but in Case 5 the staphylococcus was still present after 10 days' treatment with minimal clinical improvement and the shunt had to be removed.

Serum levels of Vancomycin.-The mean and range of serum levels of all six patients for the 10 days following $1 \mathrm{~g}$. of vancomycin by intravenous infusion are shown in Table III. Effective therapeutic levels persisted for about seven days, though often vancomycin was detectable in the serum for considerably longer than this. We measured the serum level 18 days after a 1-g. dose in two patients and recorded levels of just under $1 \mu \mathrm{g} . / \mathrm{ml}$. These low levels, however, could not be regarded as of therapeutic value. The detailed record of the serum levels in Case 3 are shown in the Chart with the dialysis periods marked. Dialysis did not affect the rate of fall of the vancomycin concentration in this patient's serum, nor in any of the other cases where relevant serial

TABle II.-Bacteriology, Therapy, and Clinical Results for Six Anuric Patients with Shunt Site Infections, Treated with Vancomycin

\begin{tabular}{|c|c|c|c|c|c|c|c|c|c|}
\hline $\begin{array}{l}\text { Case } \\
\text { No. }\end{array}$ & Age & Sex & $\begin{array}{c}\begin{array}{c}\text { Average } \\
\text { Weight } \\
(\mathrm{kg} .)\end{array} \\
\end{array}$ & Initial Shunt Swab & Sensitivity & $\begin{array}{l}\text { M.I.C. of } \\
\text { Vancomycin }\end{array}$ & $\begin{array}{l}\text { Total Dose } \\
\text { Vancomycin }\end{array}$ & $\begin{array}{l}\text { Treatment } \\
\text { Time } \\
\text { (Weeks) }\end{array}$ & Results of Treatment \\
\hline 1 & 21 & M. & 53 & Staph. coag. neg. & Resistant P, S, C & Not done & $6 \mathrm{~g}$. & 7 & reduced to + in 3 days; shunt site \\
\hline 2 & 19 & M. & 61 & Staph. coag. pos. & Resistant $\mathbf{P}$ & Not done & $4 \mathrm{~g}$. & 7 & $\begin{array}{l}\text { chinically unintected in } 5 \text { days } \\
\text { in } 5 \text { days sterile in } 7 \text { days, clinically uninfected }\end{array}$ \\
\hline 3 & 19 & M. & 54 & Repeatedly sterile & - & - & $6 \mathrm{~g}$. & 6 & Slow clinical improvement of shunt site over \\
\hline 4 & 21 & F.* & 44 & Staph. coag. pos. & Fully sensitive & $0.6 \mathrm{~kg} . / \mathrm{ml}$. & $6 \mathrm{~g}$. & 6 & Shunt site clinically uninfected within 7 days \\
\hline 5 & 31 & F.* & 39 & Staph. coag. pos. & Resistant $\mathrm{P}, \mathrm{S}, \mathrm{T}, \mathrm{E}$ & $1.2 \mu \mathrm{g} . / \mathrm{ml}$. & $6 \mathrm{~g}$. & 6 & $\begin{array}{l}\text { Staph. still present with same vancomycin M.I.C. } \\
\text { after } 10 \text { days. Shunt removed }\end{array}$ \\
\hline 6 & 32 & M.* & 54 & Staph. coag. pos. & Resistant $\mathrm{P}, \mathrm{T}$ & $1.2 \mathrm{ug} . / \mathrm{ml}$ & $6 \mathrm{~g}$. & 6 & $\begin{array}{l}\text { Shunt site clinically improved in } 7 \text { days. Staph. } \\
\text { reduced to } \pm \text { growth in } 10 \text { days }\end{array}$ \\
\hline
\end{tabular}

$\mathbf{P}=$ Penicillin. $\quad \mathbf{S}=$ Streptomycin. $\quad \mathrm{T}=$ Tetracycline. $\quad \mathrm{E}=$ Erythromycin. $\mathrm{C}=$ Cloxacillin

*Also received intermittent topical fusidic acid to shunt site.

TABLE III.-Serum Levels of Vancomycin in $\mu \mathrm{g} . / \mathrm{ml}$. Following 1-g. Doses Intravenously

\begin{tabular}{|c|c|c|c|c|c|c|c|c|c|c|c|c|c|c|c|}
\hline \multirow{2}{*}{ Case No. } & & & \multirow{2}{*}{ No. of Dose } & \multicolumn{12}{|c|}{ Days after Dose } \\
\hline & & & & $0^{*}$ & 1 & 2 & 3 & 4 & 5 & 6 & 7 & 8 & 9 & 10 & 11 \\
\hline $1 \ldots$ &. & $\cdots\{$ & $\frac{1}{2}$ & $\begin{array}{l}15 \\
15.5\end{array}$ & $\begin{array}{l}8 \cdot 2 \\
7 \cdot 7\end{array}$ & & & & & & & & & & \\
\hline $2 \ldots$ & . & .. & 1 & 17 & 13 & $9 \cdot 5$ & $4 \cdot 8$ & & $7 \cdot 4$ & 5 & & & & & \\
\hline $3 \ldots$ & . & .. & $\begin{array}{l}1 \\
2 \\
3 \\
4 \\
5 \\
6\end{array}$ & $\begin{array}{l}19 \\
15 \\
17 \\
22 \\
26\end{array}$ & 18 & $14 \cdot 5$ & $\begin{array}{l}13 \cdot 5 \\
10 \\
12 \\
8 \cdot 8\end{array}$ & $\begin{array}{c}10 \\
6 \cdot 1 \\
6 \\
9 \cdot 2 \\
5 \cdot 4 \\
10\end{array}$ & $\begin{array}{l}7.5 \\
6.4\end{array}$ & $\begin{array}{l}3 \cdot 7 \\
2 \cdot 3 \\
4 \cdot 6 \\
4 \cdot 8 \\
7 \cdot 4\end{array}$ & $\begin{array}{l}1 \cdot 5 \\
2 \\
2 \cdot 1 \\
3 \cdot 9 \\
4 \cdot 4\end{array}$ & $1 \cdot 3$ & & & \\
\hline $4 \ldots$ & .. & .. & $\begin{array}{l}1 \\
2 \\
3 \\
4 \\
5 \\
6\end{array}$ & $\begin{array}{l}35 \\
22 \\
19 \\
39 \\
31\end{array}$ & & 12 & $\begin{array}{c}8 \cdot 4 \\
11 \\
9 \cdot 6 \\
15 \\
19\end{array}$ & $\begin{array}{c}6 \cdot 4 \\
6 \cdot 9 \\
10 \\
7 \cdot 8 \\
11\end{array}$ & & $\begin{array}{l}6 \\
3 \cdot 2 \\
8.1 \\
7 \cdot 6\end{array}$ & $\begin{array}{l}2 \cdot 4 \\
9 \cdot 2 \\
4 \cdot 8 \\
5 \cdot 5 \\
3 \cdot 5\end{array}$ & & 3 & 1.9 & 2.9 \\
\hline $5 \ldots$ & .. & & $\begin{array}{l}1 \\
2 \\
3 \\
4 \\
5\end{array}$ & $\begin{array}{l}16 \cdot 5 \\
21 \\
31\end{array}$ & $\begin{array}{l}15 \\
17\end{array}$ & 10 & $\begin{array}{r}12.5 \\
6.8\end{array}$ & $\begin{array}{r}5 \\
11\end{array}$ & $\begin{array}{l}7.8 \\
5.5 \\
6.8\end{array}$ & $\begin{array}{l}2 \cdot 2 \\
0 \\
4 \cdot 4\end{array}$ & $\begin{array}{l}2 \cdot 6 \\
4\end{array}$ & $4 \cdot 7$ & $1 \cdot 7$ & & $2 \cdot 6$ \\
\hline $6 \ldots$ &.. & & 1 & $18 \cdot 4$ & $12 \cdot 8$ & $8 \cdot 8$ & & & & & & & & & \\
\hline Mean level & .. &. & & $22 \cdot 3$ & $13 \cdot 1$ & $10 \cdot 96$ & 10.95 & $8 \cdot 1$ & $6 \cdot 9$ & $4 \cdot 6$ & 3.8 & $3 \cdot 0$ & $2 \cdot 1$ & 1.9 & \\
\hline
\end{tabular}

*Taken one to three hours after intravenous infusion. 


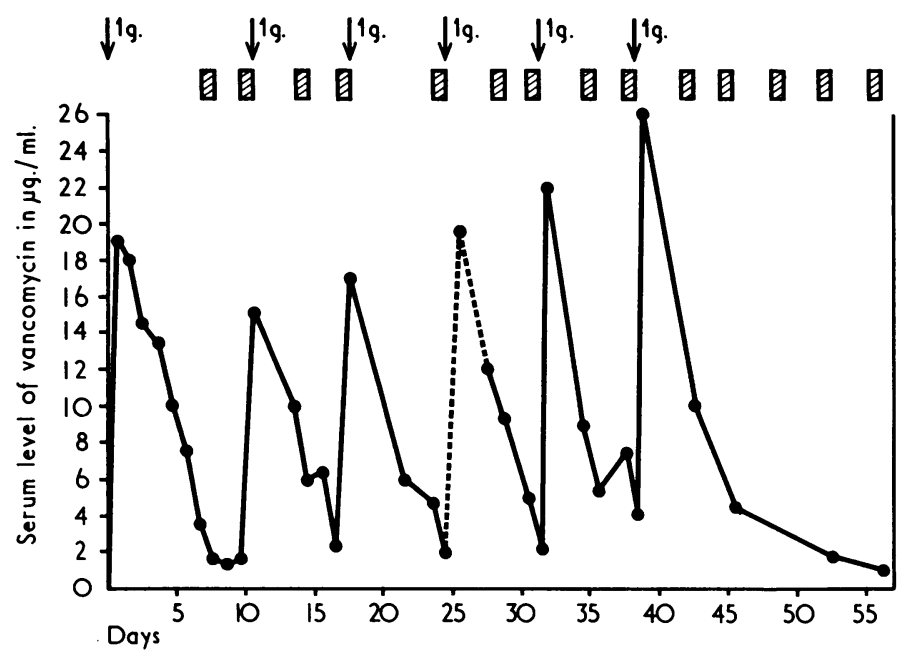

Serum levels of vancomycin following multiple 1-g. doses in Case 3. The shaded areas represent periods of dialysis.

estimations were made. Some accumulation of the drug in the serum over the six-week treatment period was found in Case 3, but this was not a consistent finding in all the patients.

\section{Discussion}

Though vancomycin-resistant staphylococci were reported to be very uncommon when the drug was first introduced, we felt it was important to carry out sensitivity tests on a range of hospital staphylococci to be sure that the situation had not altered. Since the size of the zone of inhibition obtained when using the disc method of sensitivity testing bears no relation, for vancomycin, to the minimum inhibitory concentration of the organism, minimum inhibitory concentrations of vancomycin were measured for a selection of staphylococci. The results are similar to those reported some time ago (Griffith and Peck, 1955-6; McCormick et al., 1955-6; Kirby and Divelbiss, 1956-7), and there seems to have been no change in the sensitivity of hospital staphylococci to the antibiotic; this may be attributable to its rather limited clinical use.

Vancomycin is a difficult antibiotic to assay by the agar plate diffusion technique, and it was essential to do a minimum of two separate estimations on each serum sample. Occasionally serious discrepancies occurred; these results were discounted and the assays were repeated. Even with prediffusion at $4^{\circ} \mathrm{C}$. the zones of inhibition obtained are apt to be small compared, for instance with the penicillins, and the dose-response line is steep.

The assay results obtained in six patients showed that levels of vancomycin above $2.5 \mu \mathrm{g} . / \mathrm{ml}$. persist in the serum for about seven days. Since vancomycin inhibits most staphylococci at a concentration of $2.5 \mu \mathrm{g} . / \mathrm{ml}$. and is only minimally removed during dialysis, shunt site infections can be treated with intermittent infusion of the antibiotic into the shunt. In patients with normal renal function a therapeutic regimen of $1 \mathrm{~g}$. of vancomycin every 12 hours has been recommended (Kirby and Divelbiss, 1956-7). For anuric patients Lindholm and Murray (1966) suggested that $1 \mathrm{~g}$. of vancomycin every 10 to 14 days would produce therapeutic serum levels. On the basis of our results, $1 \mathrm{~g}$. of vancomycin every seven days is necessary to maintain sufficient levels of the drug for effective treatment of staphylococcal infection. If a dose of $0.5 \mathrm{~g}$. were used, more frequent injections would be required. Since vancomycin may accumulate over several weeks' treatment, estimation of the serum level may well be required in each patient.

The treatment schedule of $1 \mathrm{~g}$. of vancomycin every seven days led to pronounced clinical improvement of the shunt site infection within a week in four of the six patients, and within two weeks in one more. It failed in only one case. Since only one infusion of the drug was given each week at the time of a routine visit to the hospital for dialysis, and since oral and intramuscular routes were avoided, the patients were not inconvenienced in any way.

We thank Dr. N. F. Jones and Dr. A. J. Wing for their helpful criticisms and permission to study these patients, Miss $\mathrm{C}$. Warren for careful technical assistance, and the sister and nurses of the renal unit for their co-operation.

Requests for reprints should be addressed to Dr. I. Phillips, Department of Clinical Microbiology, St. Thomas's Hospital, London S.E.1.

\section{REFERENCES}

Dutton, A. A. C., and Elmes, P. C. (1959). British Medical fournal, 1, 1144

Geraci, J. E., Heilman, F. R., Nichols, D. R., and Wellman, W. E. (1958). Proceedings of the Staff Meetings of the Mayo Clinic, 33, 172.

Griffith, R. S., and Peck, F. B. (1955-6). Antibiotics Annual, p. 619 Kirby, W. M. M., and Divelbiss, G. L. (1956-7). Antibiotics Annual,

indholm, D. D., and Murray, J. S. (1966). New England fournal of Medicine, 274, 1047 .

McCormick, M. H., Stark, W. M., Pittenger, G. E., Pittenger, R. C. and McGuire, J. M. (1955-6). Antibiotics Annual, p. 606.

\section{Introduction}

Though many cases of hyperosmolar non-ketotic diabetic coma have been reported (Sament and Schwartz, 1957; Danowski and Nabarro, 1965) and the association of glucose intolerance with raised blood lipid levels is recognized (Bierman and Porte, 1968) there are no well-documented studies of blood lipid levels in this condition. Two cases of hyperosmolar non-ketotic diabetic coma, one with pronounced hyperglycaemia, have been studied with particular reference to serum lipid levels. 